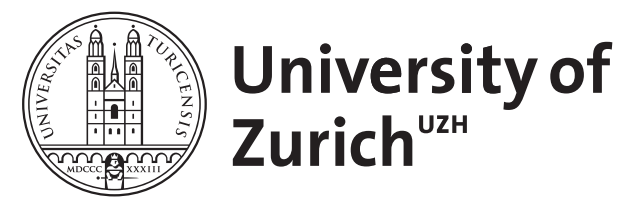

\title{
A drought index accounting for snow
}

\author{
Staudinger, Maria ; Stahl, Kerstin ; Seibert, Jan
}

\begin{abstract}
The Standardized Precipitation Index (SPI) is the most widely used index to characterize droughts that are related to precipitation deficiencies. However, the SPI does not always deliver the relevant information for hydrological drought management particularly in snow-influenced catchments. If precipitation is temporarily stored as snow, then there is a significant difference between meteorological and hydrological drought because the delayed release of melt water to the stream. We introduce an extension to the SPI, the Standardized Snow Melt and Rain Index (SMRI), that accounts for rain and snow melt deficits, which effectively influence streamflow. The SMRI can be derived without snow data, using temperature and precipitation to model snow. The value of the new index is illustrated for seven Swiss catchments with different degrees of snow influence. In particular for catchments with a larger component of snowmelt in runoff generation, the SMRI was found to be a worthwhile complementary index to the SPI to characterize streamflow droughts.
\end{abstract}

DOI: https://doi.org/10.1002/2013WR015143

Posted at the Zurich Open Repository and Archive, University of Zurich

ZORA URL: https://doi.org/10.5167/uzh-101411

Journal Article

Accepted Version

Originally published at:

Staudinger, Maria; Stahl, Kerstin; Seibert, Jan (2014). A drought index accounting for snow. Water Resources Research, 50(10):7861-7872.

DOI: https://doi.org/10.1002/2013WR015143 


\section{A drought index accounting for snow}

Maria Staudinger ${ }^{1}$, Kerstin Stahl $^{2}$ and Jan Seibert ${ }^{1,3}$

Corresponding author: M. Staudinger, Department of Geography, University of Zurich, Winterthurerstr. 180, 8057 Zurich, Switzerland. (maria.staudinger@geo.uzh.ch)

${ }^{1}$ Department of Geography, University of

Zurich, Zurich, Switzerland.

${ }^{2}$ Chair of Hydrology, Albert-Ludwigs

University Freiburg, Freiburg, Germany.

${ }^{3}$ Department of Earth Sciences, Uppsala

University, Sweden. 
2 Abstract. The Standardized Precipitation Index $(S P I)$ is the most widely

3 used index to characterize droughts that are related to precipitation deficien-

${ }_{4}$ cies. However, the $S P I$ does not always deliver the relevant information for

${ }_{5}$ hydrological drought management particularly in snow influenced catchments.

6 If precipitation is temporarily stored as snow, then there is a significant dif-

7 ference between meteorological and hydrological drought because the delayed

s release of melt water to the stream. We introduce an extension to the $S P I$,

9 the Standardized Snow Melt and Rain Index $(S M R I)$, that accounts for rain

10 and snow melt deficits, which effectively influence streamflow. The $S M R I$

${ }_{11}$ can be derived without snow data, using temperature and precipitation to

12 model snow. The value of the new index is illustrated for seven Swiss catch-

${ }_{13}$ ments with different degrees of snow influence. In particular for catchments

${ }_{14}$ with a larger component of snowmelt in runoff generation, the $S M R I$ was

15 found to be a worthwhile complementary index to the SPI to characterize

16 streamflow droughts. 


\section{Introduction}

Droughts always originate from a lack of precipitation. In some regions high tempera-

18 tures and evapotranspiration are additional important drivers of soil moisture and hydro-

19 logical droughts. In contrast to these drought processes that occur in summer, the storage

${ }_{20}$ of precipitation as ice and snow can act as a key moderator of hydrological drought. In

${ }_{21}$ particular, streamflow droughts are often related to the presence or absence of snow in

${ }_{22}$ the preceding winter period and winter droughts can occur despite large amounts of pre-

${ }_{23}$ cipitation, if the precipitation falls as snow. Van Loon and Van Lanen [2012] distinguish

${ }_{24}$ between six different hydrological drought types according to their development (classical rainfall deficit drought, rain-to-snow-season drought, wet-to-dry-season drought, cold

${ }_{26}$ snow season drought, warm snow season drought, and composite drought). Since hydro-

${ }_{27}$ logical droughts can have severe impacts on river ecology, water supply, energy production,

${ }_{28}$ or navigation, there is a need to monitor these droughts.

${ }_{29}$ Drought monitoring requires indicators that are general enough to be widely applicable,

so but specific enough to capture the type of drought relevant to the region and variable

31 of interest. The development of such indicators in the United States is summarized by

32 Heim Jr [2002]. There are only a few indices that consider snow explicitly, one of these for

33 example, is the surface water supply index (SWSI) [Shafer and Dezman, 1982; Doesken

${ }_{34}$ et al., 1991]. The Standardized Precipitation Index $(S P I)$ is an indicator for drought

35 that was first introduced by McKee et al. [1993]. Since its introduction, the SPI has been

${ }_{36}$ applied in many studies, in operational drought monitoring in the present, and also in

37 scenario predictions of drought for climate change impact assessment [e.g. Ji and Peters, 
38 2003; Ghosh and Mujumdar, 2007; Naresh Kumar et al., 2009; Orlowsky and Seneviratne,

39 2012; Naresh Kumar et al., 2009]. A major advantage of the SPI compared to other

40 drought indices is that it requires only precipitation data to describe drought severity. It

${ }_{41}$ is calculated based on a theoretical probability distribution fitted to the long-term precip-

${ }_{42}$ itation record aggregated over a chosen preceding period. This probability distribution

${ }_{43}$ is then transformed into a normal distribution so that the mean $S P I$ is zero. Positive

${ }_{44} S P I$ values indicate greater than mean precipitation, and negative values indicate less

${ }_{45}$ than mean precipitation. As the $S P I$ is standardized, wetter and drier climates are rep-

${ }_{46}$ resented in the same way allowing for regional comparison studies [Hayes et al., 1999].

${ }_{47}$ Different precipitation aggregation periods can reflect the impact of drought as it prop-

48 agates through the hydrological cycle into soil, streamflow and groundwater. Soil mois-

49 ture conditions are related to precipitation anomalies on a relatively short scale, whereas

50 streamflow for instance, reflects longer-term precipitation anomalies [Hayes et al., 1999].

${ }_{51}$ With the right aggregation time a climatic drought index such as the $S P I$ may also be

${ }_{52}$ a suitable indicator for hydrological droughts. The US Drought Monitor, for example,

53 uses composite drought indices with a focus on short SPI aggregation periods for warn-

${ }_{54}$ ings about agricultural drought impacts and composite indices with a focus on longer

${ }_{55} S P I$ aggregation periods for warnings about hydrological drought impacts (droughtmon-

${ }_{56}$ itor.unl.edu). Several studies have investigated the time lag between SPI and streamflow

${ }_{57}$ drought in order to find the most suitable $S P I$ aggregation period linked to hydrological

${ }_{58}$ drought characterization. Some researchers have determined such a time lag between me-

${ }_{59}$ teorological drought and streamflow drought [Haslinger et al., 2014], while others found

60 strong dependencies apart of areas that have a large groundwater storage [Haslinger et al., 
${ }_{61}$ 2014] or at times of snow storage [Shukla and Wood, 2008; Vidal et al., 2010].

${ }_{62}$ To create a methodologically consistent indicator of hydrological droughts, several stud-

${ }_{63}$ ies have transferred the SPI approach to observed and modeled hydrological variables.

${ }_{64}$ López-Moreno et al. [2009] and Vicente-Serrano et al. [2011] applied the SPI concept to ${ }_{65}$ observed streamflow in Spain, introducing a standardized streamflow index (SSI). Shukla

${ }_{6}$ and Wood [2008] derived a standardized runoff index $(S R I)$ for monthly aggregations of ${ }_{67}$ modeled daily grid cell runoff, which consisted of modeled surface runoff and base flow

${ }_{68}$ (subsurface flow). The results were $S R I$ maps for the entire USA based on the grid cells of ${ }_{69}$ a large-scale hydrological model. Vidal et al. [2010] applied the approach to hydrological 70 model output for France, but instead of grid cell runoff they calculated a standardized 71 flow index for the routed streamflow. Shukla and Wood [2008] and Vidal et al. [2010] com${ }_{72}$ pared their derived hydrological indices with the traditional SPI in order to explore the ${ }_{73}$ time lag of the drought propagation through the hydrological cycle. They concluded that 74 a standardized runoff index can complement the $S P I$ especially in periods when variables 75 other than precipitation become more important, e.g. periods of snow accumulation and ${ }_{76}$ melt. While the advantage is that modeled runoff considers precipitation, temperature 77 and radiation as well as information about the variability of vegetation, soil and terrain 78 characteristics, it cannot be validated. Only runoff routed to the outlet of a catchment, 79 i.e. the streamflow, can be gauged and thus validated. Unfortunately, in many catchso ments, streamflow data are influenced by human impacts or are not available for periods ${ }_{81}$ long enough to calculate an SSI based on observations.

${ }_{82}$ The $S P I$ can be modified to indicate a hydrological drought rather than a precipitation 83 drought without the full complexity of a hydrological model, by only accounting for first- 
${ }_{84}$ order controls on catchment hydrology that affect drought. Recently, Vicente-Serrano

${ }_{85}$ et al. [2010] introduced an index that accounts for evapotranspiration as an important

${ }_{86}$ amplifier of drought and found this index to be useful for catchments in Spain. This study

${ }_{87}$ specifically aimed for a climatic drought index with low data requirements which can serve

${ }_{88}$ as an indicator for hydrological drought in regions with a variable influence of snow. In

s9 such regions, e.g. mountain headwaters, streamflow is a major source of water use for

so water supply, energy production, and the ecology of mountain streams is vulnerable to

${ }_{91}$ drought. Therefore, this study uses a drought index based on observed streamflow, the

${ }_{92} S S I$, as a benchmark against which to compare the climatic drought index $S P I$ and the

${ }_{93}$ new Standardized Snow Melt and Rain Index $(S M R I)$. The comparison is done for seven

94 Swiss catchments with different amounts of snow melt contributions to streamflow.

\section{Data and Methods}

\subsection{Data}

Data from seven unregulated meso-scale catchments in Switzerland were used in this

96 study (Table 1). The mean elevation for the different catchments ranges between 700 and

${ }_{97} 2400$ ma.s.l. The catchment areas range between 20 and $350 \mathrm{~km}^{2}$, and the estimated

${ }_{98}$ fraction of annual snow in precipitation ranges between 5 and $45 \%$ (Table 1). Daily

99 precipitation and temperature data were derived from the grid products RhiresD and

${ }_{100}$ TabsD [Frei, 2013] provided by MeteoSwiss (2013). Both grid products are based on the

101 interpolation of the daily anomalies of a dense network of meteorological records on a 102 spatial background climatology. The daily grids have a spatial resolution of $2 \mathrm{~km} \times 2 \mathrm{~km}$

and cover the period 1971-2011. For this study, catchment averages of precipitation and 


\subsection{Probability distribution selection for $S P I$ and $S S I$}

For the calculation of standardized drought indices a theoretical distribution has to be chosen. The SPI has often been calculated based on the Gamma distribution, even though some authors claim that other distributions like the Pearson type III distribution might be more suitable [e.g., Guttman, 1999]. We tested different theoretical distributions as suggested by Vicente-Serrano et al. [2010, 2011]. The best fit for all variables on average was found for the Pearson type III distribution, which then served as a basis for all index calculations (SPI, SSI and the new $S M R I)$. The parameters of the distribution were estimated using the L-moments method as described by Hosking [1990].

\subsection{The Standardized Melt and Rainfall Index $(S M R I)$}

The new SMRI was calculated similarly to SPI and SSI, but from the daily sum of snow melt and rain $(M R)$. To obtain daily snow melt amounts, a commonly used snow model that only requires temperature data in addition to precipitation was first applied.

While any snow model or derivation of snow melt could be used to calculate the index, the model used here consists of a snow accumulation component based on a threshold temperature and of a snow melt component based on a degree-day approach allowing for storage of up to $10 \%$ of the current simulated snow water equivalent and refreezing of liquid water in the snow pack (at a reduced rate compared to melting) [e.g., Bergström et al., 1992] (a detailed description can be found in Appendix A). The variable $M R$ was then transformed into the index $S M R I$ using the Pearson type III distribution. 
${ }_{124}$ In order to explore the level of local parameterization needed, three parameter set ensem-

${ }_{125}$ bles were tested: the first parameter set ensemble (Set 1) assumed no prior knowledge ${ }_{126}$ (10'000 random parameter sets), the second set (Set 2) assumed some regional knowledge ${ }_{127}$ and the third set (Set 3) assumed specific catchment knowledge. Set 1 was derived from 


\subsection{Application and comparison of $S M R I$ to $S P I$ and $S S I$}

All indices were calculated for different aggregation periods (1, 2, 3, 4, 6 and 12 months), referred to as, for instance $S M R I-6$ for the $S M R I$ calculated based on a six months preceding aggregation period. If no aggregation period is specified results refer to all aggregation periods.

To compare the new $S M R I$ as well as the $S P I$ to our variable of interest, the $S S I$, a benchmark model efficiency $F_{\text {bench }}$ (Eq. 1, [Schaefli and Gupta, 2007]) was used as one measure of comparison. $F_{\text {bench }}$ was calculated as the ratio of the quadratic absolute errors; subtracting the ratio from one transforms it to a range of minus infinity to one. A value of one for $F_{\text {bench }}$ corresponds to a perfect fit of the $S S I$ and $S M R I$. Values larger than zero indicate that the $S M R I$ is closer to the $S S I$ than the $S P I$ and values below zero indicate that the $S P I$ is closer to the $S S I$ than the $S M R I$.

$$
F_{\text {bench }}=1-\frac{\sum\left(x_{S S I}(t)-x_{S M R I}(t)\right)^{2}}{\sum\left(x_{S S I}(t)-x_{S P I}(t)\right)^{2}}
$$

$F_{\text {bench }}$ was calculated for both the entire index time series (1971-2011) as well as for the hydrological dry periods only $(S S I<0)$.

In addition to this general evaluation, we looked at two historical drought events in particular: the summer drought of 2003 [Rebetez et al., 2006] as well as the spring drought of 2011. The summer drought 2003 was caused by a lack of precipitation and, due to extremely high temperatures, also high evapotranspiration rates. The drought in spring 


\section{Results}




\section{Discussion}

\subsection{Uncertainties from model and index standardization}


Precipitation and Evapotranspiration Index $(S P E I)$, which uses an evapotranspiration estimation in the first step [Vicente-Serrano et al., 2010, 2012] this two-step process means that the resulting index has multiple sources of uncertainty. The most important sources of uncertainty from the snow model are the parameterization of the degree-day model, the spatial discretization of elevation as well as data uncertainty. Model parameterization and spatial discretization were addressed by ensemble approaches using parameterizations stemming from no prior knowledge, regional knowledge and specific catchment knowledge.

The calculation of the actual index is then influenced by semi-objective decisions including that for a theoretical distribution function and finally the choice for an aggregation period to be used.

The Monte Carlo approach that was used is a common way to test the sensitivity to model parameterization [e.g., Demaria et al., 2007]. The results showed variation in the performance of the $S M R I$. However, for the snow influenced catchments and for most parameter combinations, the entire parameter range resulted in an $S M R I$ that was much closer to a hydrological drought description than the SPI for both the entire observation period as well as for the dry periods only. For the catchments with less snow influence there is no disadvantage compared to the $S P I$. Increasing the knowledge about the snow model parameters of a catchment decreased the uncertainty. However, there was not an increase but a slight decrease of the performance found. This decrease is counter-intuitive s5o but might be explained by the fact that the prior knowledge parameters were derived by calibration of a full hydrological model. The optimal snow parameter values derived in 252 this way might be model specific and not be those providing best results for the SMRI, ss when soil or groundwater were not considered. These results indicate that the use of an 
311 as the one in spring 2011.

${ }_{312}$ The slightly greater performance difference between $S M R I_{\text {elev }}-1$ and $S M R I-1$ compared 
$337 \quad$ situations.

\section{Conclusions}




$$
\begin{aligned}
& \text { if } T(t)<T_{T} \text { then } \\
& R(t)=\min \left(S_{\text {liquid }}(t-1), C_{F R} * C_{M} *\left(T_{T}-T(t)\right)\right) \\
& A(t)=A(t-1)+P(t)+R(t) \\
& S_{\text {liquid }}(t)=S_{\text {liquid }}(t-1)-R(t) \\
& \text { else } \\
& M(t)=\min \left(A(t-1), C_{M} *\left(T(t)-T_{T}\right)\right) \\
& \quad A(t)=A(t-1)-M(t) \\
& \quad S_{\text {liquid }}(t)=S_{\text {liquid }}(t-1)+P(t)+M(t) \\
& \text { if } S_{\text {liquid }}(t)>C_{W H} * A(t) \text { then } \\
& \quad Q(t)=S_{\text {liquid }}(t)-C_{W H} * A(t) \\
& \quad S_{\text {liquid }}(t)=C_{W H} * A(t)
\end{aligned}
$$

end if

end if

Acknowledgments. Support from the Swiss National Research Program Sustainable Water Management (NRP 61, project DROUGHT-CH) is gratefully acknowledged. The authors thank FOEN and MeteoSwiss for providing the data used in this study and three anonymous reviewers, which helped to considerably improve the manuscript. Many thanks to Tracy Ewen for improving the language. 


\section{References}

Bergström, S., J. Harlin, and G. Lindström (1992), Spillway design floods in sweden: I. new guidelines, Hydrological Sciences Journal, 37(5), 505-519.

Cancelliere, A., and J. D. Salas (2010), Drought probabilities and return period for annual streamflows series, Journal of Hydrology, 391 (1), 77-89.

Choi, H. T., and K. Beven (2007), Multi-period and multi-criteria model conditioning to reduce prediction uncertainty in an application of topmodel within the glue framework, Journal of Hydrology, 332(3), 316-336.

Demaria, E. M., B. Nijssen, and T. Wagener (2007), Monte carlo sensitivity analysis of land surface parameters using the variable infiltration capacity model, Journal of Geophysical Research: Atmospheres (1984-2012), 112(D11).

Doesken, N. J., T. B. McKee, and J. D. Kleist (1991), Development of a surface water supply index for the western United States: Final report, Colorado State University, Department of Atmospheric Science.

Esko, K. (1980), On the values and variability of degree-day melting factor in finland, Nordic hydrology, $11(5), 235-242$.

FOEN (2012), Federal Office for the Environment, section of hydrology.

Frei, C. (2013), Interpolation of temperature in a mountainous region using nonlinear profiles and non-euclidean distances, International Journal of Climatology, pp. 15851605.

Ghosh, S., and P. Mujumdar (2007), Nonparametric methods for modeling gcm and scenario uncertainty in drought assessment, Water Resources Research, 43(7), W07,405. 
Guttman, N. (1999), Accepting the standardized precipitation index: a calculation algorithm, Journal of the American Water Resources Association, 35(2), 311-322.

Haslinger, K., D. Koffler, W. Schöner, and G. Laaha (2014), Exploring the link between meteorological drought and streamflow: Effects of climate-catchment interaction, Water Resources Research, pp. 2468-2487.

Hayes, M. J., M. D. Svoboda, D. A. Wilhite, and O. V. Vanyarkho (1999), Monitoring the 1996 drought using the standardized precipitation index, Bulletin of the American Meteorological Society, 80(3), 429-438.

Heim Jr, R. (2002), A review of twentieth-century drought indices used in the united states, Bulletin of the American Meteorological Society, 83(8), 1149-1165.

Hock, R. (2003), Temperature index melt modelling in mountain areas, Journal of Hydrology, 282(1), 104-115.

Hosking, J. (1990), L-moments: analysis and estimation of distributions using linear combinations of order statistics, Journal of the Royal Statistical Society. Series B (Methodological), pp. 105-124.

Ji, L., and A. Peters (2003), Assessing vegetation response to drought in the northern great plains using vegetation and drought indices, Remote Sensing of the Environment, $87(1), 85-98$.

Lindström, G. (1997), A simple automatic calibration routine for the hbv model, Nordic Hydrology, 28(3), 153-168.

Lindström, G., B. Johansson, M. Persson, M. Gardelin, and S. Bergström (1997), Development and test of the distributed hbv-96 hydrological model, Journal of Hydrology, $201(1), 272-288$. 
López-Moreno, J., S. Vicente-Serrano, S. Beguería, J. García-Ruiz, M. Portela, and A. Almeida (2009), Downstream propagation of hydrological droughts in highly regulated transboundary rivers: the case of the tagus river between spain and portugal, Water Resources Research, 45, W02,405.

McKee, T., N. Doesken, and J. Kleist (1993), The relationship of drought frequency and duration to time scales, in Proceedings of the 8th Conference on Applied Climatology, vol. 17, pp. 179-183, American Meteorological Society Boston, MA.

Merz, R., and G. Blöschl (2004), Regionalisation of catchment model parameters, Journal of Hydrology, 287(1), 95-123.

Montanari, A. (2005), Large sample behaviors of the generalized likelihood uncertainty estimation (glue) in assessing the uncertainty of rainfall-runoff simulations, Water Resources Research, 41(8).

Naresh Kumar, M., C. Murthy, M. Sesha Sai, and P. Roy (2009), On the use of standardized precipitation index (spi) for drought intensity assessment, Meteorological Applications, $16(3), 381-389$.

Orlowsky, B., and S. I. Seneviratne (2012), Global changes in extreme events: regional and seasonal dimension, Climatic Change, 110(3), 669-696.

Pappenberger, F., and K. J. Beven (2004), Functional classification and evaluation of hydrographs based on multicomponent mapping (mx), International Journal of River Basin Management, 2(2), 89-100.

Rasmussen, R., B. Baker, J. Kochendorfer, T. Meyers, S. Landolt, A. P. Fischer, J. Black, J. M. Thériault, P. Kucera, D. Gochis, et al. (2012), How well are we measuring snow: The noaa/faa/ncar winter precipitation test bed., Bulletin of the American Meteorolog- 
ical Society, 93(6), 811-829.

Rebetez, M., H. Mayer, O. Dupont, D. Schindler, K. Gartner, J. P. Kropp, and A. Menzel (2006), Heat and drought 2003 in europe: a climate synthesis, Annals of Forest Science, 63(6), 569-577.

Schaefli, B., and H. V. Gupta (2007), Do nash values have value?, Hydrological Processes, $21(15), 2075-2080$.

Seibert, J. (1999), Regionalisation of parameters for a conceptual rainfall-runoff model, Agricultural and Forest Meteorology, 98, 279-293.

Seibert, J. (2000), Multi-criteria calibration of a conceptual runoff model using a genetic algorithm, Hydrology and Earth System Sciences, 4(2), 215-224.

Seibert, J., and M. Vis (2012), Teaching hydrological modeling with a user-friendly catchment-runoff-model software package, Hydrology and Earth System Sciences, 16(9), $3315-3325$

Shafer, B., and L. Dezman (1982), Development of a surface water supply index (swsi) to assess the severity of drought conditions in snowpack runoff areas, in Proceedings of the Western Snow Conference, vol. 50, pp. 164-175.

Shukla, S., and A. Wood (2008), Use of a standardized runoff index for characterizing hydrologic drought, Geophysical Research Letters, 35(2), L02,405.

Uhlenbrook, S., J. Seibert, C. Leibundgut, and A. Rodhe (1999), Prediction uncertainty of conceptual rainfall-runoff models caused by problems in identifying model parameters and structure, Hydrological Sciences Journal, 44(5), 779-797.

Van Loon, A., and H. Van Lanen (2012), A process-based typology of hydrological drought, Hydrology and Earth System Sciences, 16(7), 1915-1946. 
${ }_{464}$ van Vliet, M. T., J. R. Yearsley, F. Ludwig, S. Vögele, D. P. Lettenmaier, and P. Kabat (2012), Vulnerability of us and european electricity supply to climate change, Nature Climate Change, 2(9), 676-681.

${ }_{467}$ Vicente-Serrano, S., S. Beguería, and J. López-Moreno (2010), A multiscalar drought ${ }_{468}$ index sensitive to global warming: the standardized precipitation evapotranspiration ${ }_{469}$ index, Journal of Climate, 23(7), 1696-1718.

${ }_{470}$ Vicente-Serrano, S., J. López-Moreno, S. Beguería, J. Lorenzo-Lacruz, C. Azorin-Molina, ${ }_{471}$ and E. Morán-Tejeda (2011), Accurate computation of a streamflow drought index, ${ }_{472}$ Journal of Hydrologic Engineering, 17(2), 318-332.

${ }_{473}$ Vicente-Serrano, S. M., S. Beguería, J. Lorenzo-Lacruz, J. J. Camarero, J. I. López${ }_{474}$ Moreno, C. Azorin-Molina, J. Revuelto, E. Morán-Tejeda, and A. Sanchez-Lorenzo (2012), Performance of drought indices for ecological, agricultural, and hydrological applications., Earth Interactions, 16(10).

${ }_{477}$ Vidal, J., E. Martin, L. Franchistéguy, F. Habets, J. Soubeyroux, M. Blanchard, M. Bail${ }_{478}$ lon, et al. (2010), Multilevel and multiscale drought reanalysis over france with the 479 safran-isba-modcou hydrometeorological suite, Hydrology and Earth System Sciences, ${ }_{480} \quad 14(3), 459-478$. 
Table 1. Catchment properties (FOEN, Section Hydrology, 2011).

\begin{tabular}{|c|c|c|c|c|c|c|}
\hline Catchment number & Name & $\begin{array}{l}\text { Area } \\
\left(\mathrm{km}^{2}\right)\end{array}$ & $\begin{array}{r}\text { Mean elevation } \\
\text { (ma.s.l.) }\end{array}$ & $\begin{array}{l}\text { Elevation range } \\
\text { (ma.s.l.) }\end{array}$ & Regime & $\begin{array}{r}\text { Snow } / \text { precip }^{a} \\
(\%)\end{array}$ \\
\hline 1 & Mentue & 105.0 & 679 & $445-927$ & pluvial & 4.8 \\
\hline 2 & Sense & 352.0 & 1068 & $548-2189$ & pluvio-nival & 11.7 \\
\hline 3 & Sitter & 74.2 & 1252 & $769-2501$ & nival & 22.7 \\
\hline 4 & Allenbach & 28.8 & 1856 & $1297-2762$ & nival & 33.7 \\
\hline 5 & Riale di Calneggia & 24.0 & 1996 & $885-2921$ & nival & 34.3 \\
\hline 6 & Ova da Cluozza & 26.9 & 2368 & $1508-3165$ & nival & 42.2 \\
\hline 7 & Dischma & 43.3 & 2372 & $1668-3146$ & nival & 44.7 \\
\hline
\end{tabular}

a Percent of snow in precipitation is calculated as the ratio of precipitation on days with air temperatures below $0^{\circ} \mathrm{C}$ and precipitation from the entire observational period

Table 2. Mean values of $F_{\text {bench }}$ for different aggregation periods and all catchments.

\begin{tabular}{|c|c|c|c|c|c|c|c|}
\hline $\begin{array}{l}\text { Aggregation time } \\
\text { [months }]\end{array}$ & Mentue & Sense & Sitter & $\begin{array}{l}\text { Riale di } \\
\text { Calneggia }\end{array}$ & Allenbach & $\begin{array}{l}\text { Ova da } \\
\text { Cluozza }\end{array}$ & Dischma \\
\hline \multicolumn{8}{|l|}{ Full period } \\
\hline 1 & 0.008 & 0.079 & 0.197 & 0.341 & 0.332 & 0.573 & 0.465 \\
\hline 2 & 0.010 & 0.093 & 0.226 & 0.366 & 0.405 & 0.610 & 0.479 \\
\hline 3 & 0.011 & 0.100 & 0.268 & 0.396 & 0.448 & 0.629 & 0.488 \\
\hline 4 & 0.012 & 0.104 & 0.284 & 0.424 & 0.468 & 0.639 & 0.492 \\
\hline 6 & 0.012 & 0.107 & 0.261 & 0.438 & 0.476 & 0.620 & 0.475 \\
\hline 12 & -0.003 & 0.029 & 0.073 & 0.181 & 0.182 & 0.333 & 0.187 \\
\hline \multicolumn{8}{|l|}{ Dry periods } \\
\hline 1 & 0.004 & 0.059 & 0.216 & 0.386 & 0.296 & 0.635 & 0.514 \\
\hline 2 & 0.004 & 0.065 & 0.215 & 0.390 & 0.361 & 0.667 & 0.541 \\
\hline 3 & 0.005 & 0.064 & 0.245 & 0.412 & 0.393 & 0.679 & 0.558 \\
\hline 4 & 0.008 & 0.067 & 0.251 & 0.436 & 0.412 & 0.685 & 0.553 \\
\hline 6 & 0.011 & 0.083 & 0.265 & 0.438 & 0.453 & 0.649 & 0.498 \\
\hline 12 & -0.009 & 0.026 & 0.097 & 0.192 & 0.164 & 0.352 & 0.193 \\
\hline
\end{tabular}




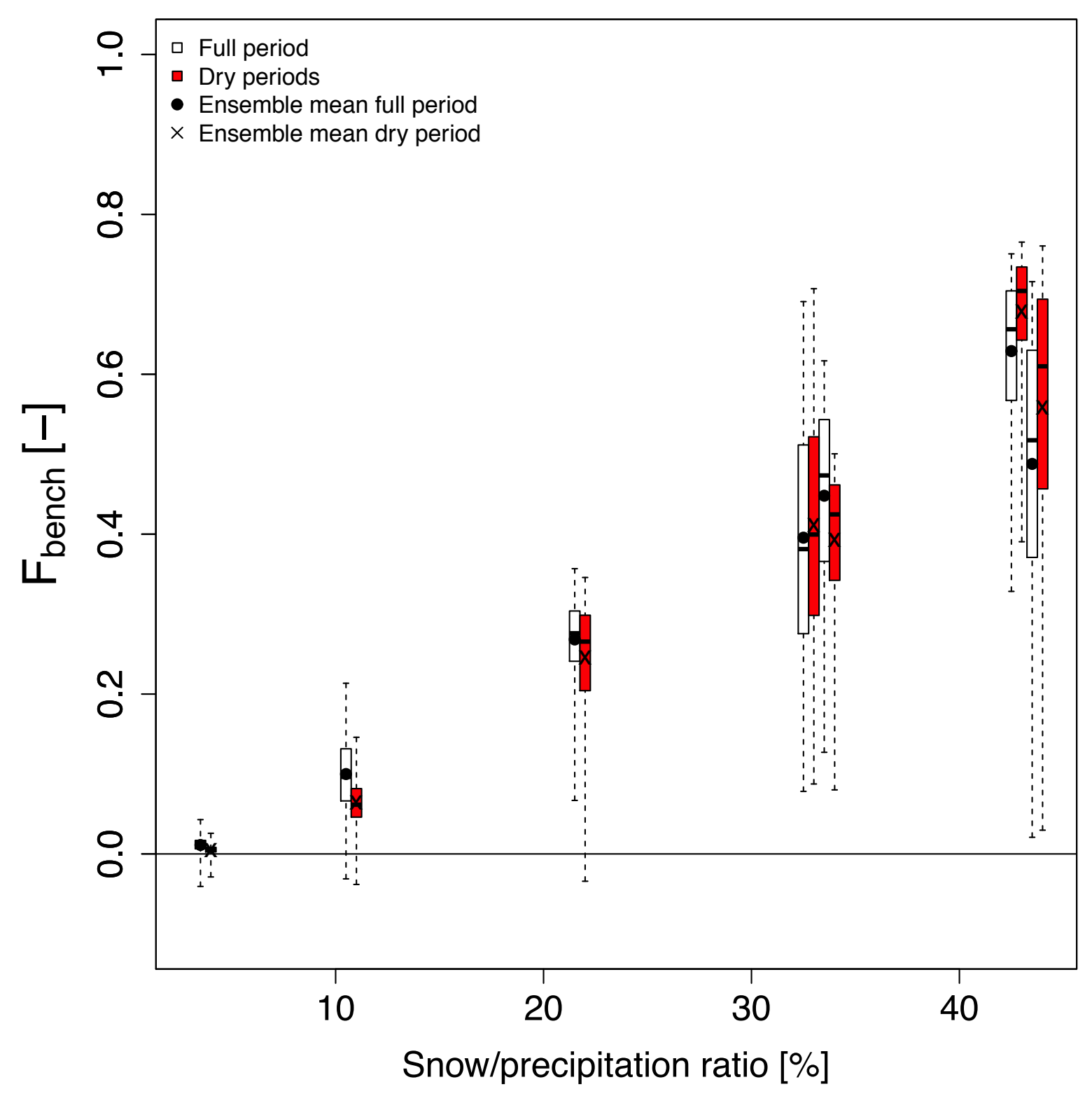

Figure 1. Distributions of the measure of comparison $F_{\text {bench }}$ for snow model parameter Set 1 for drought indices with an aggregation period of three months. Each pair of boxes (white plus red) represents one catchment. Additionally, the measure of comparison of the ensemble mean is shown. The whiskers of a boxplot extend to the minimum and the maximum values, the box extends from the 25 th to the 75 th percentile and the bar shows the median. 


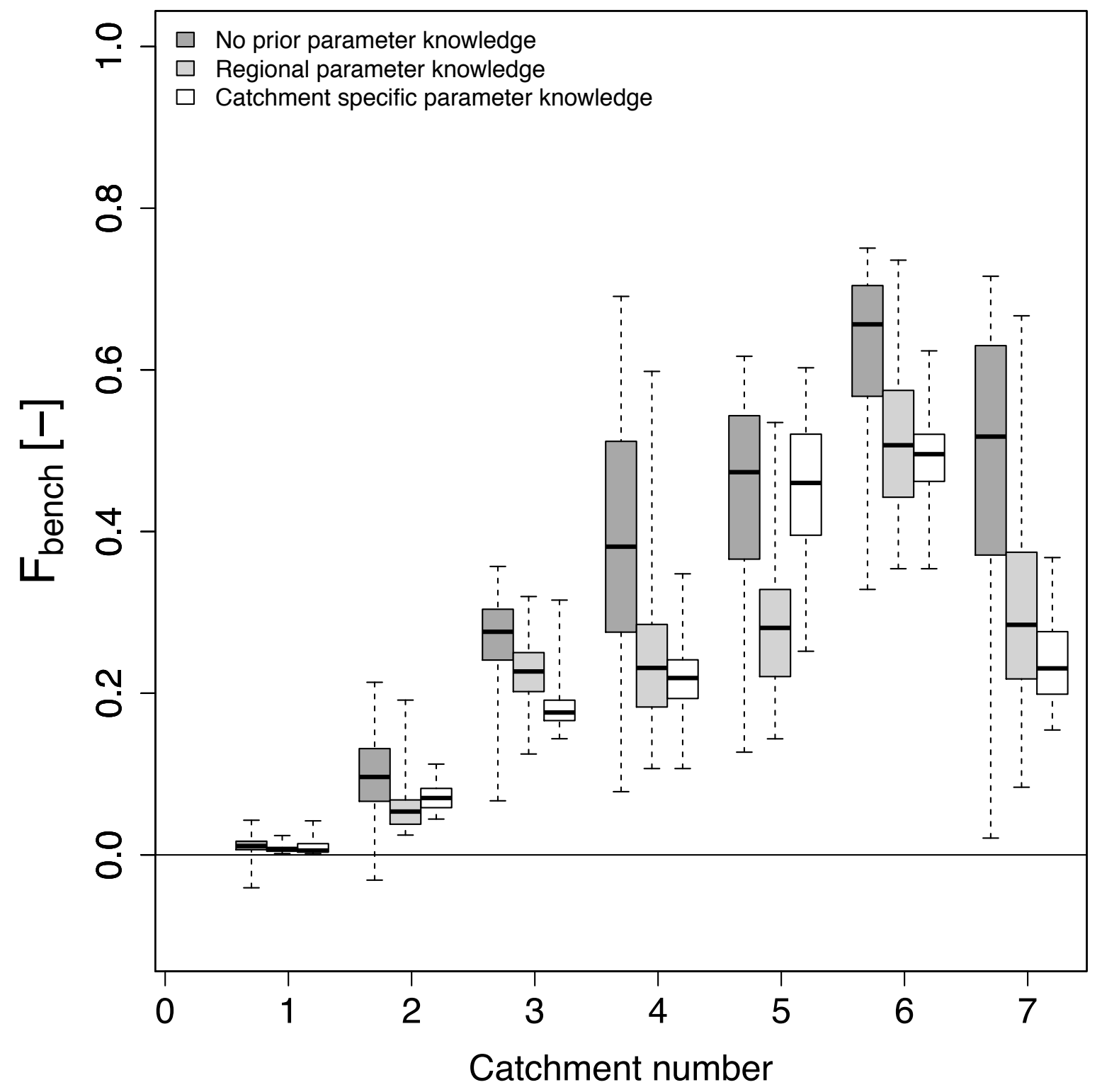

Figure 2. Distributions of the measure of comparison $F_{\text {bench }}$ for the three different snow model parameter sets for drought indices with an aggregation period of three months. Boxplots as in Figure 1. 


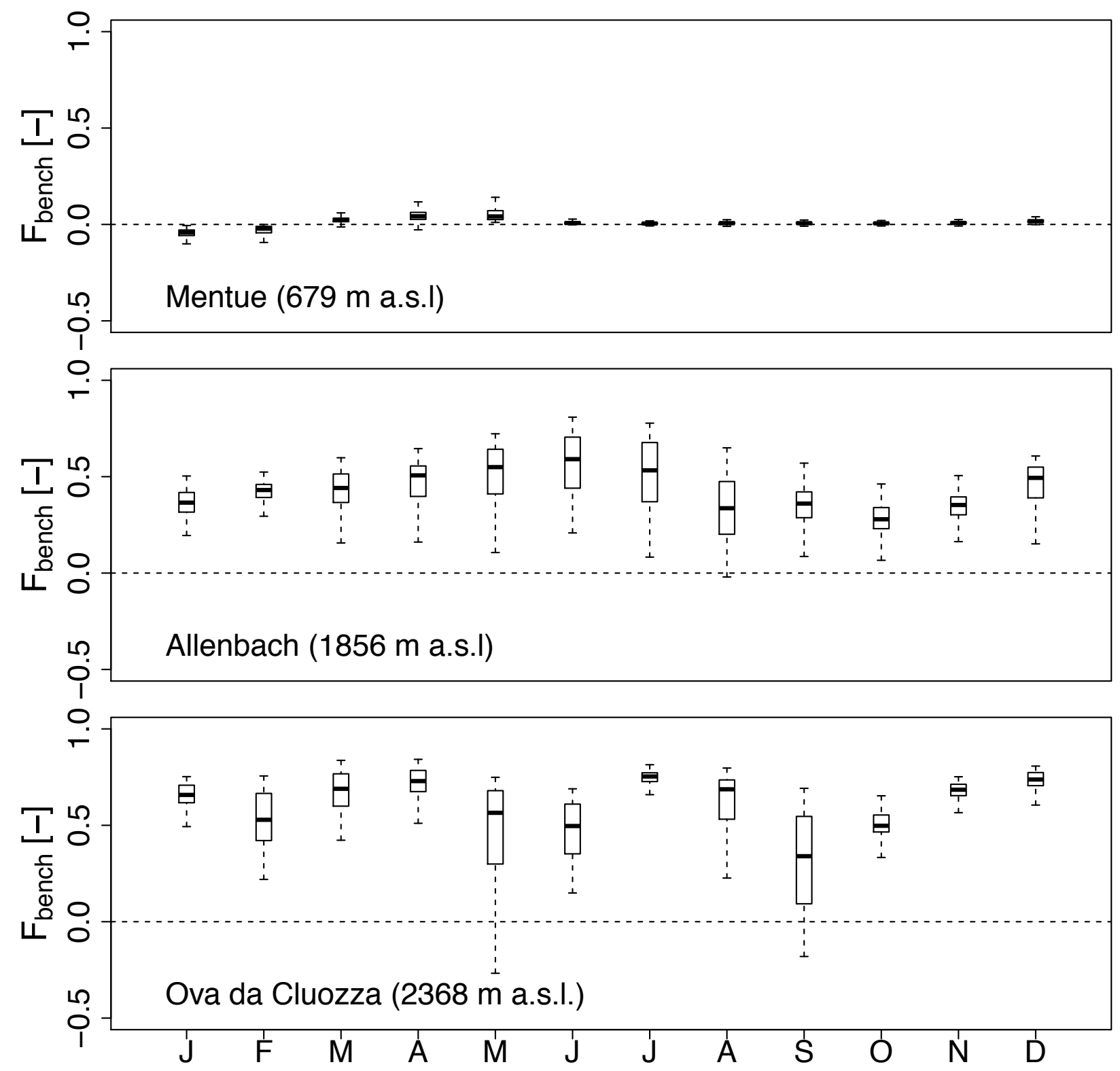

Figure 3. Distributions of the measure of comparison $F_{\text {bench }}$ for each month, modeled with Set 1 for a catchment with little snow influence (upper), a catchment with medium snow influence (middle) and a catchment with high snow influence (lower). Boxplots as in Figure 1. 

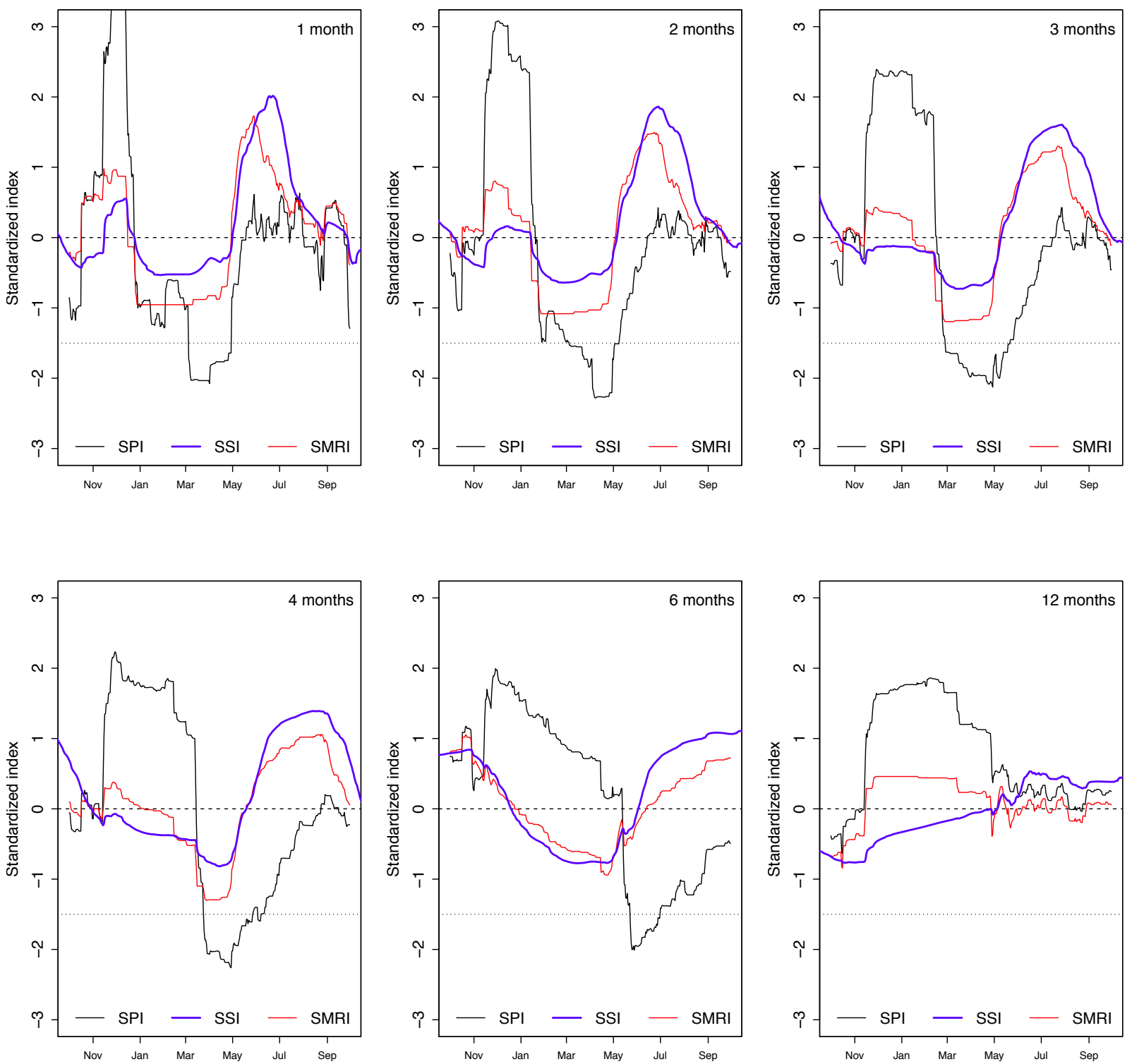

Figure 4. Standardized precipitation $(S P I)$ (black), streamflow $(S S I)$ (blue) and ensemble mean of the snow melt rain index $(S M R I)$ (red) in daily resolution for six different accumulation periods during the summer drought 2003 for the nival Ova da Cluozza catchment. 

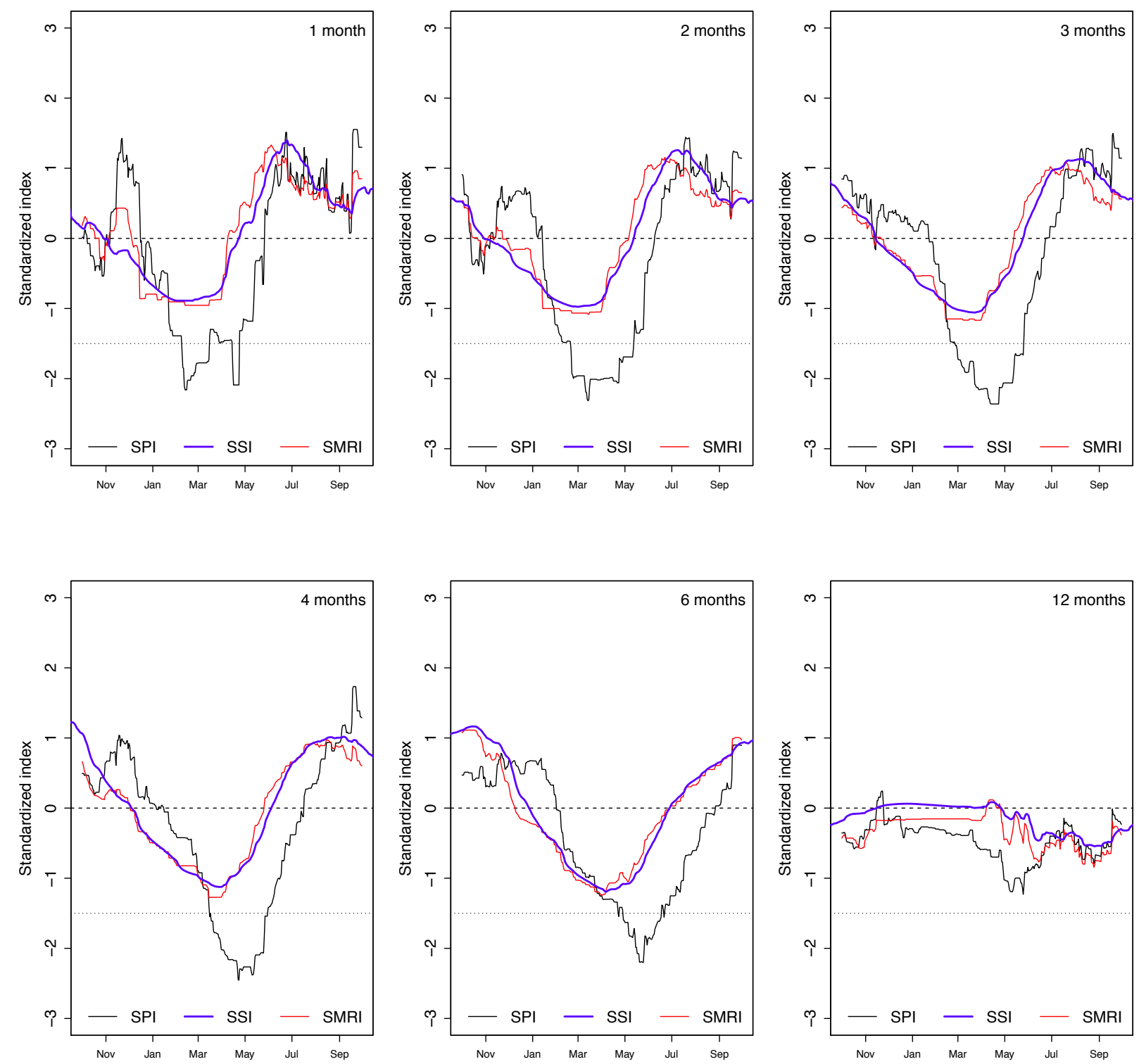

Figure 5. Standardized precipitation $(S P I)$ (black), streamflow $(S S I)$ (blue) and ensemble mean of the snow melt rain index $(S M R I)$ (red) in daily resolution for six different accumulation periods during the spring drought 2011 for the nival Ova da Cluozza catchment. 


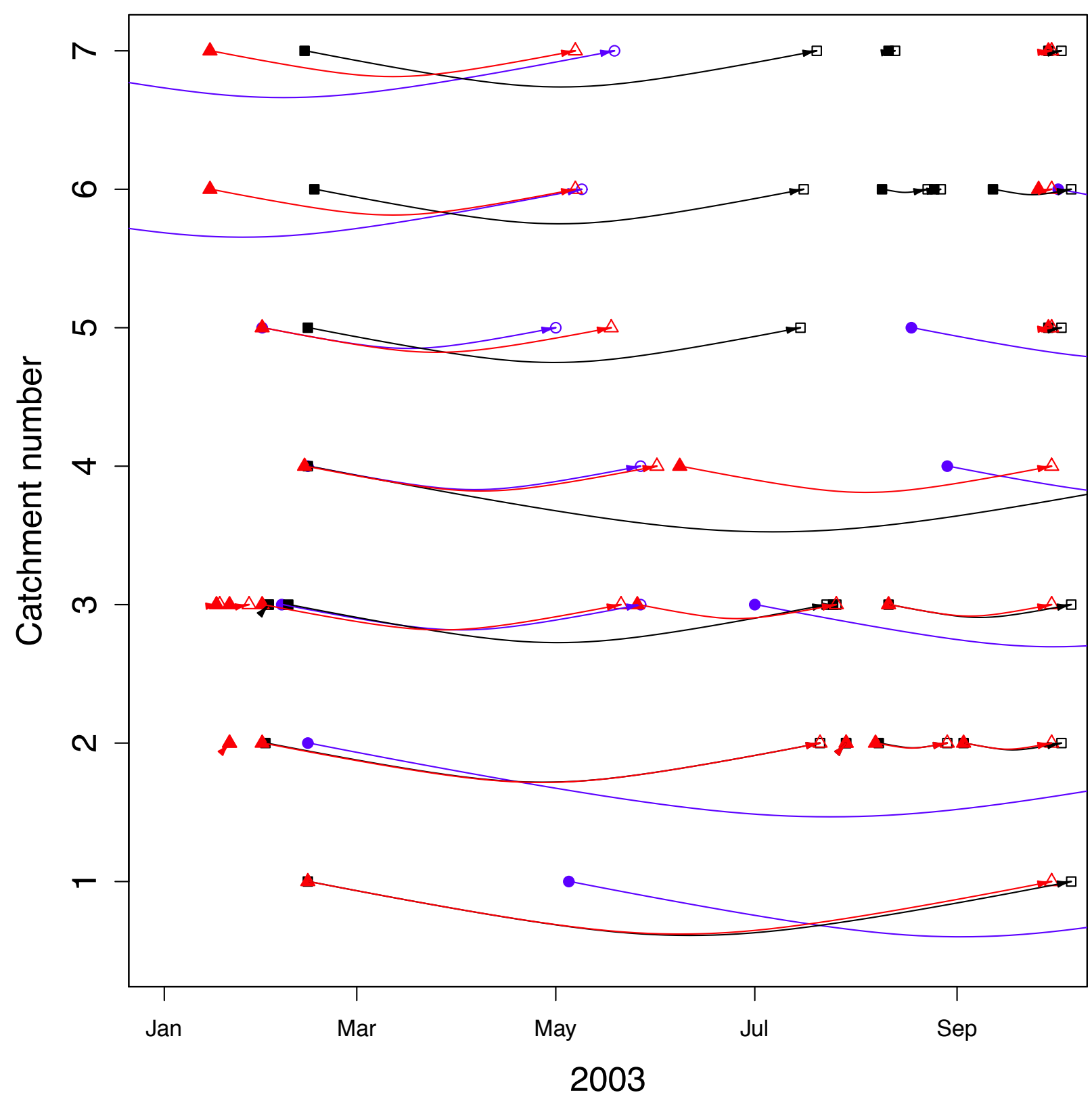

Figure 6. Starting dates of the summer drought 2003 (index $<0$ ) for standardized precipitation $(S P I)$ (black), streamflow $(S S I)$ (blue) and ensemble mean of the snow melt rain index $(S M R I)$ (red) for the accumulation period of three months. 


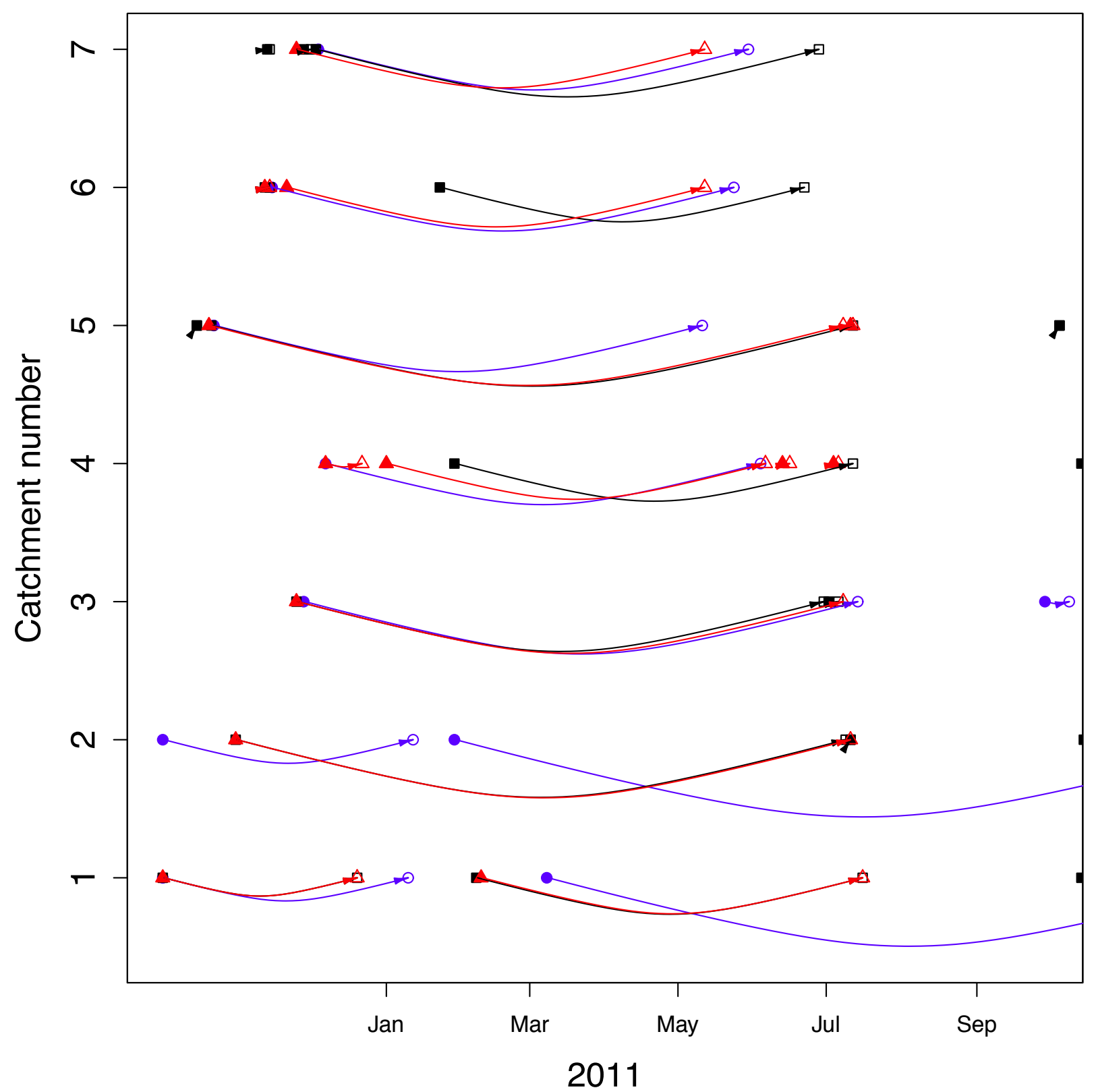

Figure 7. Starting dates of the spring drought 2011 (index $<0$ ) for standardized precipitation $(S P I)$ (black), streamflow $(S S I)$ (blue) and ensemble mean of the snow melt rain index $(S M R I)$ (red) for the accumulation period of three months. 

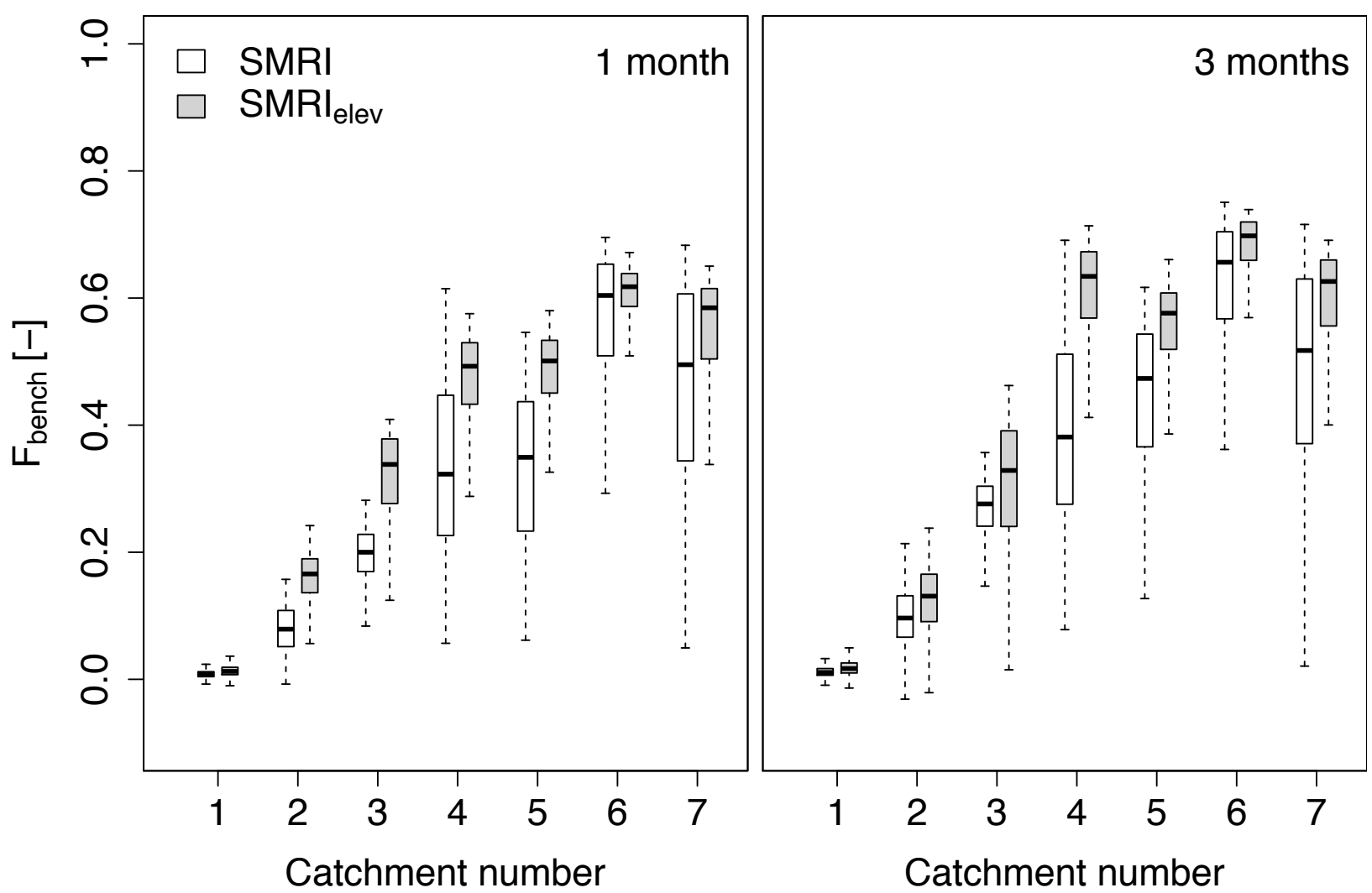

Figure 8. Comparison of the distribution of the measure of comparison for $S M R I$ and $S M R I_{\text {elev }}$ for the aggregation periods of one (left) and three (right) months. Boxplots as in Figure 1. 